\title{
Analysis of business process maturity and organisational performance relations
}

T. Bartosz Kalinowski, Ph.D.

University of Lodz Faculty of Management

\section{Introduction}

The concept of maturity, depending on the source, may vary significantly. Humphrey defined process maturity as "the degree of explicit definition, management, measurement, control and effectiveness a process has" (Humphrey 1987, pp. 1-13). Furthermore it is stated that immature organisations lack with formal management, tend to improvise on processes, are reactionary and identify difficulties with meeting set deadlines. On the contrary, mature organisations, possess accurate documentation of processes and work activities, which are executed according to planned processes. Worldwide research conducted among different types of companies (Harmon, Wolf 2014, pp 1-10) prove that organisations are increasingly becoming process oriented and the maturity of their processes and organisation as a whole is systematically improving.

The paper aims to present results of the study on business process maturity in relation to organisational performance. A two-phase methodology, based on literature review and survey was used. The literature is a source of knowledge about business process maturity and organisational performance, whereas the 
research on process maturity vs organisational performance in Polish Enterprises provides findings based on 84 surveyed companies. The main areas of the research covered: identification and analysis of maturity related variables, as well as identification of organisational performance perspectives and its relation to process maturity. Although there are research on such relation available, they are scarce and have some significant limitations in terms of research sample or the scope of maturity or organisational performance covered.

\section{Maturity}

The concept of maturity is usually linked with business practice trough business process maturity models. Maturity models find their origin in the work of R. Nolan (1973) and P. Crosby (1979). Maturity models can generally be characterized as frameworks or reference models with sets of enablers and management practices required for obtaining operational efficiency of both processes and organisation. These models can be also used as a tool to determine the state of existing, on-going processes ("as-is" state), while the aim of their application is to achieve a desirable, future state of the processes ("to-be" state). The transition between the states is described through maturity levels (Becker et al. 2009, pp. 213-222; Gottschalk 2009, pp. 75-81; Kazanjian, Drazin 1989, pp. 1489-1503).

A framework that is widely adopted in practice is Capability Maturity Model (CMM/CMMI), developed by the Software Engineering Institute (SEI)/Carnegie Mellon University (Humphrey 1987, pp. 1-13). Initially, the CMM/CMMI was developed for the assessment of software development processes maturity, however later it was found to be applicable in other industries and processes. The CMM/CMMI classifies business processes into five subsequent "maturity levels", which became a standard framework for process maturity classifications. The CMM/CMMI distinguishes the following maturity levels:

- initial (a.k.a. chaotic, ad hoc): processes are not documented, the organisation lacks a formal process management and processes are ineffectively planned,

- repeatable: processes are at least documented sufficiently and are under such statistical control that repeating the same steps may be attempted,

- defined: processes are defined/confirmed as a standard business process and decomposed,

- managed: processes are quantitatively managed in accordance with agreedupon metrics,

- optimized: measured processes create the foundation for continuing improvement and optimization. 
According to available studies more than 150 different models of processes maturity can be identified (Kalinowski 2012, pp. 334-352), however the exact number is difficult to establish. A large number of new maturity models (34 new maturity models) was developed in 2009 and 2010 alone (Wendler 2012, pp. 13171339). Most of the models used for studies are based on CMM/CMMI approach and organisational performance concept formulated by Rummler and Brache (1990).

"The motley array of maturity models" (Curtis, Alden 2007, pp. 1-5) gives no evidence for delivering a new proposal for process maturity model. For this reason the model used for this study was developed on the basis of CMM/ CMMI concept and its descriptions of maturity levels. A few elements, such as IT related practices, have been added as they are considered important in the literature and business practice (Hammer, 2007) and are not directly present in the CMM/CMMI concept. Finally the content of the model and survey was designed taking into account the core elements of business process management identified by Rosemann and vom Brocke (2015) and design principles formulated by M. Röglinger, J. Pöppelbuß and J. Becker (2012).

\section{Performance}

Maturity models have emerged as a measure to evaluate the capabilities of an organisation in a certain discipline and in a number of studies maturity is defined as the ability to systematically provide better business results, thus links with process and/or organisational performance (Rosemann, De Bruin 2005, pp. 1-21; Hammer 2007, pp. 111-123).

Performance has been presented and categorized in literature in several ways (Kihn, 2010, pp. 468-492). One way is to: a) distinguish the outcomes of organisational activities and b) the means by which these outcomes are reached (Govindarajan, Fisher 1990, pp. 259-285). The former (a) is often called "effectiveness" (Ukko 2009, pp. 25-27) while the latter (b) is referred to as "efficiency" (Ukko 2009, pp. 25-27).

Another way to characterize performance is to distinguish between financial and non-financial performance (Ittner 2008, pp. 261-272). The financial performance is often measured using traditional accounting key performance indicators (KPIs) such as ROA, ROS, EBIT, EVA or sales growth (Crabtree, DeBusk 2008, pp. 8-15). The non-financial performance can be measured using operational KPIs, such as market share, innovation rate or customer satisfaction (Hyvönen 2007, pp. 343-366). 
The CMM and other maturity models operate as a tool that enables organisations to rank specific processes according to how well they are implemented, managed, measured and optimized. Processes that have a higher rank - also called a higher level of maturity - are claimed to be associated with better performance of those processes and in particular with better quality output. This claim is supported by a large number of studies (e.g.: Jiang et al. 2003, pp. 279-288; Herbsleb et al. 1997, pp. 30-40; Škrinjar et al. 2008, pp. 738-754; McCormack et al. 2009, pp. 792815; Nowosielski 2012, pp. 354-369).

\section{Design and results of the survey}

The main aim of the study described in the article was to investigate the relation between process maturity and organisational performance. Therefore a research question studied in this paper has been stated as: Does higher process maturity lead to better organisational performance?

The maturity related practices used in research have been based on CMM/ CMMI assumptions, however they have been simplified to 59 components organised into 7 business process management (BPM) areas. This step was taken due to the fact that business process management practitioners perceived the full specification of CMM/CMMI, with over 300 components requiring assessment in order to establish the maturity level of the organisation, as too complex. This view was also supported in pilot studies trough in-depth interviews with business process management practitioners.

The organisational performance sub-constructs were operationalised by developing several items based on a literature review (e.g. Baird et al. 2011, pp. 789-814; Kaynak 2003, pp. 405-435; Martensen et al. 2007, pp. 51-65).

Table 1. Sample characteristics

\begin{tabular}{l|c|c}
\hline \multirow{2}{*}{ Characteristics } & Values & $\begin{array}{c}\text { Number of } \\
\text { respondents }\end{array}$ \\
\hline \multirow{4}{*}{ Size (employees) } & $0-5$ & 10 \\
\cline { 2 - 3 } & $6-50$ & 21 \\
\cline { 2 - 3 } & $51-250$ & 32 \\
\cline { 2 - 3 } & $251-500$ & 11 \\
\hline
\end{tabular}




\begin{tabular}{|c|c|c|}
\hline \multirow{5}{*}{$\begin{array}{c}\text { Age of process management } \\
\text { system }\end{array}$} & $0-2$ & 8 \\
\hline & $3-5$ & 11 \\
\hline & $6-10$ & 23 \\
\hline & Over 11 & 20 \\
\hline & During implmentation & 22 \\
\hline \multirow{14}{*}{ Sector/type of industry } & Manufacturing - electro mechanics & 11 \\
\hline & Distribution - electro mechanics & 11 \\
\hline & Manufacturing - steel and metal & 14 \\
\hline & Distribution - steel and metal & 10 \\
\hline & Manufacturing - chemicals & 13 \\
\hline & Distribution - chemicals & 13 \\
\hline & Manufacturing - food processing & 8 \\
\hline & Distribution - food processing & 10 \\
\hline & Manufacturing - clothing and textiles & 4 \\
\hline & Distribution - clothing and textiles & 6 \\
\hline & Construction services & 7 \\
\hline & IT services & 1 \\
\hline & Logistics services & 8 \\
\hline & Financial services & 2 \\
\hline \multirow{12}{*}{$\begin{array}{l}\text { Management systems and } \\
\text { concepts used }\end{array}$} & ISO 9001 & 5 \\
\hline & ISO/TS 16949 & 23 \\
\hline & ISO 14001 & 10 \\
\hline & ISO 27001 & 6 \\
\hline & ISO 22000 & 2 \\
\hline & ISO 26000 & 13 \\
\hline & Lean Management & 8 \\
\hline & Six Sigma & 7 \\
\hline & Total productive maintenance (TPM) & 16 \\
\hline & Total quality management (TQM) & 0 \\
\hline & EFQM Excellence Model & 3 \\
\hline & Balanced scorecard (BSC) & 41 \\
\hline
\end{tabular}




\begin{tabular}{l|c|c}
\multirow{3}{*}{ Function in the organisation } & Top manager & 28 \\
\cline { 2 - 3 } & Process / Department manager & 34 \\
\cline { 2 - 3 } & Lower manager & 22 \\
\hline \multirow{2}{*}{ Source: own study }
\end{tabular}

The collection of data for the study took place between November 2014 and February 2015. An on-line questionnaire was sent to 1015 companies selected from commercial databases. The questionnaire was addressed to managers and staff responsible for process management. A total number of 123 responses were collected, however only 84 of them were completed fully and included to the final research sample and analysed in this study.

Table 1 presents descriptive statistics of the research sample, showing the size of the organisation in terms of the number of employees, the age of the process managements system, industry sector in which the organisation operates, management systems and concepts used and finally the function of the respondent in the organisation.

The model used for the survey was based on sub-constructs grouped into BPM areas that include: Principles/Strategy; Process description/Management; Employees; Teamwork; Objectives; Measurement and Improvement. Furthermore every BPM area has been characterised with specific process maturity practices (e.g. Processes are described - there are procedures and/or graphic descriptions of processes (maps); Employees perceive the organisation as a system of interrelated processes; Process objectives are regularly reviewed and updated when necessary; etc.) and described in terms of CMM/CMMI maturity levels in which they fit. In order to assess the maturity level of the companies included in the research sample, a five-point Likert scale was used. The scale indicated the perception of BPM area components presence in the surveyed companies. The marginal values were defined as follows: 1 - the statement does not describe my organisation (there is no evidence for the existence of such approach in the organisation) and 5 - the statement fully describes my organisation (there is strong evidence for the existence of such approach in all areas of the organisation).

The performance measured in the survey has been composed from the following sub-constructs: Manufacturing performance; Financial and market performance; Quality performance; Innovation performance; Environmental performance and Social/HR performance. Every sub-constructs was described in terms of specific performance related results that could be observed in the 
company (e.g. Unit cost of manufacturing; Return on investment (ROI); The ability to meet targets; The number of innovations; etc.). In order to assess the performance of the organisation, a five-point Likert scale was used. The scale indicated the perception of organisational performance in the above mentioned perspectives over the last 3 years.

In order to measure the study validity, the following measures have been taken (Straub et al., 2004, pp. 380-427):

- content validity, by aligning the questions with existing measurement instruments from literature and by having the questions examined for content validity by an expert panel of process management professionals,

- construct validity, by analysing factorial validity, using factor analysis,

- construct reliability, by analysing the internal consistency of the constructs, using Cronbach's Alpha.

In order to answer the research question and examine the relation between process maturity and organisational performance, Pearson correlation was used and the results are presented in the table 2.

Table 2. Intercorrelations and Cronbach's Alpha for BPM areas and performance perspectives

\begin{tabular}{|c|c|c|c|c|c|c|c|}
\hline $\begin{array}{l}\text { BPM areas / } \\
\text { Performance } \\
\text { perspectives }\end{array}$ & 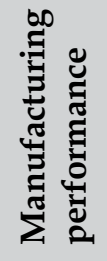 & 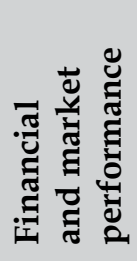 & 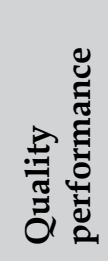 & 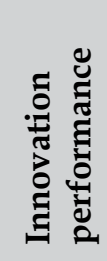 & 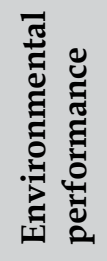 & 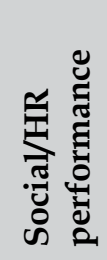 & 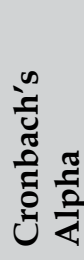 \\
\hline Principles/Strategy & $.477^{* *}$ & $.560 * *$ & $.552 * *$ & $.429 * *$ & $.460^{* *}$ & $.476^{* *}$ & .840 \\
\hline $\begin{array}{l}\text { Process description / } \\
\text { Management }\end{array}$ & $.369^{* *}$ & $.419^{* *}$ & $.568^{* *}$ & $.471^{* *}$ & $.427^{* *}$ & $.417^{* *}$ & .928 \\
\hline Employees & $.470^{* *}$ & $.429 * *$ & $.590 * *$ & $.532^{* *}$ & $.447^{* *}$ & $.500 * *$ & .897 \\
\hline Teamwork & $.402^{* *}$ & $.411^{* *}$ & $.576^{* *}$ & $.495^{\star *}$ & $.399 * *$ & $.394^{* *}$ & .882 \\
\hline Objectives & $.432^{* *}$ & $.438^{* *}$ & $.559 * *$ & $.497^{* *}$ & $.431^{* *}$ & $.415^{* *}$ & .835 \\
\hline Measurement & $.464^{* *}$ & $.497^{* *}$ & $.514^{* *}$ & $.478^{* *}$ & $.485^{* *}$ & $.481^{* *}$ & .929 \\
\hline Improvement & $.471^{* *}$ & $.476^{* *}$ & $.596^{* *}$ & $.606^{* *}$ & $.468^{* *}$ & $.478^{* *}$ & .947 \\
\hline Cronbach's alpha & .809 & .880 & .827 & .879 & .774 & .680 & - \\
\hline
\end{tabular}

Source: own study $(* * p=0,01)$ 
The study showed that there is a significant positive relation $(p=0,01)$ between the BPM areas, and organisational performance. Therefore it can be concluded that organisations that report strong evidence for the existence of certain process maturity practices in all areas of the organisation (thus represent higher process maturity), can be expected to perform better. The strength of correlation between elements varied, however interestingly the most positive impact of implementing process maturity practices could be observed on quality performance. This can be explained by the fact that quality oriented results are often associated with process management in general and as most of the surveyed companies reported to have implemented management systems (such as ISO 9001, ISO 14001 or ISO 27001) or management concepts (such as Lean Management, Six Sigma or Total Productive Maintenance) it is very probable that this relation was recognized and understood in this way. Furthermore many of the respondents were either process managers or management systems representatives. Therefore this kind of relation was reflected by their position in the organisation.

In order to validate the quality of the theoretical construct Cronbach's alpha has been used. The results of the calculation have proven that internal consistency of BPM areas constructs is excellent $(\alpha \geq 0.9)$ or good $(0.9>\alpha \geq 0.8)$, whereas internal consistency of performance perspectives is mostly good $(0.9>\alpha \geq 0.8)$. In one case it can be classified as acceptable $(0.8>\alpha \geq 0.7)$ and in another as questionable $(0.7$ $>a \geq 0.6)$. Nevertheless in management studies Cronbach's alpha values of 0.6 and above are generally accepted by researchers. Confirmatory factor analysis was used as a complementary method. In order to test the quality of the model, Kaiser criterion and Cattell's scree plot were used, both confirming proper composition of the analysed constructs without necessity to identify additional factors within BPM areas or performance perspectives.

\section{Conclusions, limitations and future research}

The stated research question: "Does higher process maturity lead to better organisational performance?" can be answered positively. The study showed that there is a significant positive relation between process maturity described in the 7 BPM areas (Principles/Strategy; Process description/Management; Employees; Teamwork; Objectives; Measurement; Improvement) and organisational performance divided into 6 perspectives (Manufacturing performance; Financial and market performance; Quality performance; Innovation performance; Environmental performance; Social/HR performance). 
The results obtained in this study are widely supported by available research. As companies improve their management systems and change existing process management practices in order to become more process oriented they inevitably optimize their processes and organisational structures that support them. There is a number of sources (e.g. Davenport 1993, pp. 240-243; McCormack, Johnson 2001, p. 12; Burlton 2001, pp. 52-112) that supports the view that higher process maturity will be reflected in better organisational performance (similarly as in the preformed research). Additionally increasing the process maturity level has significant impact on many areas of organisation. For example, it changes the way employees work and interact. As functional silos are broken down and business processes start to be integrated, inter-functional conflicts decrease and inter-departmental connectedness increases. Process maturity can also influence the interaction between a company and its business partners (suppliers and customers). Integrating processes beyond the boundaries of a single organisation (transaction based cooperation) is transformed into long-term partnership that results in increased performance for all links in a supply chain (Hendricks, Singhal, Stratman 2007, pp. 65-82; Cousins, Menguc 2006, pp. 604-620).

In order to support the research results on a more detailed level, further analysis discusses the relations between selected specific BPM areas and organisational performance dimensions. One of the most important aspects of process maturity implementation success is proactive implementation of business process management reflected in principles, strategy and management. Lack of connectivity between those element was found to be one of the main reasons for failures and poor performance of organisation in all areas (Bandara, Indulska, Chong, Sadiq 2007, pp. 1-8). Another crucial aspect reflected in the research is measurement. Process maturity is inevitably associated with change (process improvement). It is important that the measures are performed at the activity/process level where the prime effects are expected. Processes must be measured for time, costs, productivity, quality, and capital, then compared to the processes they replaced (Guha, Kettinger 1993, pp. 13-22). All key processes should be measured at critical steps in the process to meet customer requirements, prevent errors, reduce variability, improve cycle time or increase productivity, consequently leading to improved performance (Lee, Dale 1998, pp. 214-255). Lastly the available literature supports a strong correlation between employee related management practices and business performance (Beccalli 2007, pp. 2205-2230).

Summarizing, the results from this study regarding the relation of BPM areas, and organisational performance are generally in line with results that were 
presented in other available studies. However, this study novelty derives from the fact, that BPM maturity was related with different perspectives of performance, while previous studies showed the relation between BPM maturity and the performance of the organisation as a whole or only focused on selected aspect of performance (e.g. financial performance).

The results of the performed study have practical implications for managers. As companies improve their processes and are focusing on attaining higher levels of process maturity it enables them to improve their relationship with key stakeholders, employees, customers, and suppliers by creating a suitable environment for conducting business. The result of operating in such environment is better performance in different perspectives. Therefore, as business environment gets more competitive process maturity concept offers a way to adapt to new conditions and circumstances. As higher process maturity leads to better organisational performance, managers should familiarize themselves with this concept and practical implementation issues. What needs to be examined are: current practices, structures, management and measurement processes. After identifying the current state, maturity models can serve as road maps for managers' improvement efforts.

Nevertheless, several limitations of this study should be discussed. Firstly, the data collection method was based on managers' perceptions. As reported by Dearborn and Simon (1958), managers respond to questionnaires from their own local environment, which may or may not reflect what is going on in the organisation as a whole. Consequently, it is rather dangerous to readily assume that an individual response is a reliable and valid indicator of an organisationlevel construct (Venkatraman, Grant 1986, pp. 71-87). However, the use of manager's perceptions is one of the most frequently used in quality management research (Madu 1998, pp. 348-355).

Secondly, the sample size is relatively small. The results of this study should not be generalized beyond what is reasonable, given the nature of the sample. Future studies should consider substantially larger samples including greater representation of industries and/or countries.

Thirdly, the research sample focused on organisation used management systems requirements (e.g. ISO 9001), that are based on process approach. Another limitation of that study was that research questionnaires could have been primarily returned by those companies in which process management approach is implemented successfully (thus the process maturity is higher), whereas the organisations that encountered obstacles in applying the principles of process management, might have ignored the request for completing 
the survey. The commercial databases that were used for sample selection, did not report any information on management standards implementation. However the results showed that all companies participating in the study reported to have implemented some management systems or concepts (see table 1). It may mean that although the research questionnaire was targeted for all types of companies (including those with less formalized management systems), the request for completion was primarily answered by companies more mature in terms of process management. Therefore an additional conclusion from this study might be that implementation of management standards or concepts, based on process approach, is essential for achieving process maturity.

Finally, there is an increasing awareness that, whether a higher level of maturity leads to better performance, may depend on certain properties of that organisation (Niehaves et al. 2014, pp. 90-106). For some organisations the optimal level of maturity may not necessarily be the highest level of maturity. In particular, there is a strong belief among researchers and practitioners that maturity models make organisations rigid and bureaucratic (Adler et al. 2005, pp. 215-227; Antoniol et al. 2004, pp. 33-50) and, therefore, negatively affect performance and this needs to be further investigated.

\section{Summary}

\section{Analysis of business process maturity and organisational performance relations}

The paper aims to present results of the study on business process maturity in relation to organisational performance. A two-phase methodology, based on literature review and survey was used. The literature is a source of knowledge about business process maturity and organisational performance, whereas the research on process maturity vs organisational performance in Polish Enterprises provides findings based on 84 surveyed companies. The main areas of the research covered: identification and analysis of maturity related variables and identification of organisational performance perspectives and its relation to process maturity. The study shows that there is a significant positive relation between process maturity and organisational performance. Although there are research on such relation available, they are scarce and have some significant limitations in terms of research sample or the scope of maturity or organisational performance covered. This 
publication is part of a project funded by the National Science Centre awarded by decision number DEC-2011/01/D/HS4/04070.

Keywords: process maturity, process management, organisational performance.

\section{Streszczenie}

\section{Analiza relacji pomiędzy dojrzałością procesową i wynikami organizacji}

Celem artykułu jest przedstawienie wyników badań dotyczących relacji dojrzałości procesowej i wyników osiąganych przez organizacje. Zastosowana metodyka obejmowała przegląd literatury przedmiotu i badania kwestionariuszowe zrealizowane na próbie 84 przedsiębiorstw. Literatura była źródłem wiedzy na temat dojrzałości procesowej oraz efektywności organizacyjnej, z kolei badania dostarczyły wiedzy na temat wpływu dojrzałości realizowanych procesów na wyniki osiągane przez polskie przedsiębiorstwa z różnych branż. Główne obszary badań obejmowały: identyfikację i analizę praktyk determinujących dojrzałość procesową organizacji oraz określenie wymiarów efektywności, w których to zjawisko należy rozpatrywać $\mathrm{w}$ przedsiębiorstwach. $\mathrm{W}$ wyniku badań stwierdzono, że istnieje zależność pomiędzy dojrzałością procesową a wynikami osiąganymi przez organizację. Pomimo tego, że $\mathrm{w}$ literaturze przedmiotu opisane sac podobne badania, to po pierwsze ich liczba jest niewielka, a po drugie posiadają one istotne ograniczenia, zarówno jeśli chodzi o zakres próby badawczej, jak również przyjętą definicję efektywności organizacyjnej. Publikacja powstała w ramach projektu sfinansowanego ze środków Narodowego Centrum Nauki przyznanych na podstawie decyzji numer DEC-2011/01/D/HS4/04070.

\section{Słowa}

kluczowe: dojrzałość procesowa, zarzadzanie procesowe, wyniki organizacji, efektywność.

\section{References}

1. Adler, P.,McGarry, F., Irion-Talbot,W., Binney, D. (2005), Enabling process discipline: lessons from the journey to CMM Level 5, "MISQ Executive" Vol. 4, Iss. 1, pp. 215-227. 
2. Antoniol, G., Gradara, S., Venturi, G. (2004), Methodological issues in a CMM Level 4 implementation. Software Process, "Improvement and Practice" Vol. 9, Iss. 1, pp. 33-50.

3. Baird, K., Hu, K.J., Reeve, R. (2011), The relationships between organisational culture, total quality management practices and operational performance, "International Journal of Operations \& Production Management" Vol. 31, Iss. 7, pp. 789-814.

4. Bandara, W., Indulska, M., Chong, S., Sadiq, S. (2007), Major issues in business process management: An expert perspective, "BPTrends" Vol. 3, Iss. 10, pp. 1-8.

5. Becker, J., Knackstedt, R., Pöppelbuß, J., (2009), Developing maturity models for IT management - a procedure model and its application, "Business and Information Systems Engineering" Vol. 1, Iss. 3, pp. 213-22.

6. Burlton, R.T. (2001), Business process management: Profiting from process, Sams, Indianapolis.

7. Cousins, P. D., Menguc, B. (2006), The implications of socialization and integration in supply chain management, "Journal of Operations Management" Vol. 24, Iss. 4, pp. 604-620.

8. Crabtree, A. D., DeBusk, G. K. (2008), The effects of adopting the balanced scorecard on shareholder returns, "Advances in Accounting" Vol. 24, Iss. 1, pp. 8-15.

9. Crosby, P. (1979), Quality is free, McGraw-Hill, New York.

10. Curtis, B., Alden, J. (2007)., Maturity Model du Jour: A Recipe for Side Dishes, BPTrends, http://www.bptrends.com/publicationfiles/10-07-COLmaturitymodeldujour-CurtisAlden-final.pdf (05.05.2013 - access date).

11. Davenport, T.H. (1993), Process innovation: Reengineering work through information technology, Harvard Business School Press, Boston.

12. Dearborn, D.C. Simon, H.A. (1958), Selective perception: a note on the departmental identification of executives, "Sociometry", Vol. 21, Iss. 3, pp. 140-104.

13. Gottschalk, P. (2009), Maturity levels for interoperability in digital government, "Government Information Quarterly" Vol. 26, No. 1, pp. 75-81.

14. Govindarajan, V., Fisher, J., (1990), Strategy, control systems and ressource sharing: Effects on business-unit performance, "Academy of Management Journal" Vol. 33, Iss. 2, pp. 259-285.

15. Guha, S., Kettinger, W. J. (1993), Business process reengineering, "Information Systems Management" Vol. 10, Iss. 3, pp. 13-22.

16. Hammer M., (2007), The Process Audit, "Harvard Business Review" Vol. 85, Iss. 4, pp. 111-123.

17. Harmon, P., Wolf, C., (2014), The State of Business Process Management, BPTrends, http://www.bptrends.com/bpt/wp-content/uploads/ BPTrends-State-of-BPM-Survey-Report.pdf (12.04.2014 - access date). 
18. Hendricks, K. B., Singhal, V. R., Stratman, J. K. (2007), The impact of enterprise systems on corporate performance: A study of ERP, SCM, and CRM system implementations, "Journal of Operations Management" Vol. 25, Iss. 2, pp. 65-82.

19. Herbsleb, J., Zubrow, D., Goldenson, D., Hayes, W., Paulk, M. (1997), Software quality and the capability maturity model, "ACM" Vol. 40, Iss. 6, pp. 30-40.

20. Humphrey, W.S. (1987), Characterizing the software process: A maturity framework, Carnegie Mellon University/Software Engineering Institute, Pittsburgh.

21. Hyvönen, J. (2007), Strategy, performance measurement techniques and information technology of the firm and their links to organisational performance, "Management Accounting Research" Vol. 18, Iss. 3, pp. 343-366.

22. Ittner, C. D. (2008), Does measuring intangibles for management purposes improve performance?: A review of the evidence, "Accounting \& Business Research" Vol. 38, Iss. 3, pp. 261-272.

23. Jiang J.J., Klein G., Hwang H.G., Huang J., Hung S.Y. (2003), An exploration of the relation between software development process maturity and project performance, "Information and Management" Vol. 41, Iss. 3, pp. 279-288.

24. Kalinowski, T.B. (2012), A process management implementation model vs. the maturity of processes in Polish companies, Proceedings from 18th IGWT Symposium - Technology and Innovation for Sustainable Future, Rome.

25. Kaynak, H. (2003), The relationship between total quality management practices and their effects on firm performance, "Journal of Operations Management" Vol. 21, Iss. 4, pp. 405-435, DOI: 10.1016/S0272-6963(03)00004-4.

26. Kazanjian, R.K., Drazin, R. (1989), An empirical test of a stage of growth progression model, "Management Science" Vol. 35, Iss. 12, pp. 1489-1503.

27. Kihn, L.A. (2010), Performance outcomes in empirical management accounting research. Recent developments and implications for future research, "International Journal of Productivity and Performance Management" Vol. 59, Iss. 5, pp. 468-492.

28. Lee, R., Dale, B. (1998), Business process management: A review and evaluation, “Business Process Management Journal" Vol. 4, Iss. 3, pp.214-225.

29. Madu, C.N. (1998), An empirical assessment of quality: research considerations, "International Journal of Quality Science", Vol. 3, Iss. 4, pp. 348-355.

30. Martensen, A., Dahlgaard, J.J., Park-Dahlgaard, S.M. and Grønholdt, L. (2007), Measuring and diagnosing innovation excellence - simple contra advanced approaches: a Danish study, "Measuring Business Excellence" Vol. 11, Iss. 4, pp. 51-65, DOI: 10.1108/13683040710837928.

31. McCormack, K. P., Johnson, W. C. (2001), Business process orientation Gaining the e-business competitive advantage, St. Lucie Press, Florida. 
32. McCormack, K., Willems, J., van den Bergh, J., Deschoolmeester, D., Willaert, P., Stemberger, M.I., Skrinjar, R., Trkman, P., Ladeira, M.B., Valadares de Oliveira, M.P., Vuksic, V.B., Vlahovic, N. (2009), A global investigation of key turning points in business process maturity, "Business Process Management Journal" Vol. 15, No. 5, pp. 792-815.

33. Nolan, R. (1973), Managing the crisis in data processing, "Harvard Business Review", Vol. 57, Iss. 2, pp. 115-126.

34. Nowosielski, S. (2012), Dojrzałość procesowa a wyniki ekonomiczne organizacji, "Prace Naukowe Uniwersytetu Ekonomicznego we Wroclawiu", No. 264, pp. 354-369.

35. Röglinger, M., Pöppelbuß, J., Becker, J. (2012), Maturity models in business process management, "Business Process Management Journal" Vol. 18, Iss. 2, pp.328-346.

36. Rosemann, M., De Bruin, T. (2005), Application of a Holistic Model for Determining BPM Maturity, BPTrends, http://www.bptrends. com/publicationfiles/ 02-05\% 20WP\%20Application \% 20of \% 20a \% 20 Holistic\%20 Model-\%20Rosemann-Bruin\%20-\%E2\%80\%A6.pdf (11.042012 - access date).

37. Rosemann, M., vom Brocke, J., (2015), The six core elements of business process management, [in:] vom Brocke, J., Rosemann, M., (ed.), Handbook on Business Process Management Vol. 1, Springer, New York.

38. Rummler, G.A., Brache, A.P. (1990), Improving Performance: How to Manage the White Space on the Organisation Chart, Jossey-Bass, San Francisco.

39. Škrinjar, R., Bosilj-Vukšić, V., Indihar-Štemberger, M. (2008), The impact of business process orientation on financial and non-financial performance, "Business Process Management Journal" Vol. 14, Iss. 5, pp. 738-754.

40. Straub, D.W., Boudreau, M.-C., Gefen, D. (2004), Validation guidelines for is positivist research, "Communications of the Association for Information Systems" Vol. 13, Iss. 24, pp. 380-427.

41. Tangen, S. (2003), An overview of frequently used performance measures, "Work Study" Vol. 52, Iss. 7, pp. 347-354.

42. Ukko, J. (2009), Managing through measurement: A framework for successful operative level performance measurement, PhD thesis at the Lappeenranta University of Technology.

43. Venkatraman, N., Grant, J.H. (1986), Construct measurement in organisational strategy research: a critique and proposal, "Academy of Management Review" Vol. 11, Iss. 1, pp. 71-87.

44. Wendler, R. (2012), The maturity of maturity model research: a systematic mapping study, "Information and Software Technology" Vol. 54, Iss. 12, pp. 1317-1339. 